\title{
The European Partnership with Mercosur: a Relationship Based on Strategic and Neo-liberal Principles
}

\author{
SEBASTIAN SANTANDER \\ Université Libre de Bruxelles, Belgium
}

\begin{abstract}
Since the early 1990s, the European Union has developed new instruments to consolidate its external action, especially in 'low politics'. These new instruments include the signing of interregional arrangements with other regional groups. The EU's region-to-region strategy towards the Common Market of the South (Mercosur) is in keeping with the latest trends of interregionalism. Since the birth of Mercosur, the EU has given technical, financial and diplomatic support to South America's new regionalism. The long-term goal is to conclude a region-to-region agreement in the political, cooperation and trade fields. By providing this support, the EU plays a role as an 'external federator' for new regional experiences through its interregionalist projects. Although 'new interregionalism' is a corollary of the new regionalism, interregionalism can contribute to the consolidation of regionalism. Moreover, by encouraging economic multilateralism, interregional arrangements can improve the governance of globalisation.
\end{abstract}

KEY WORDS: European Union, Mercosur, interregionalism, regionalism, United States, Free Trade Area of the Americas

\section{Introduction}

New regionalism, as a trend, has been developing for more than fifteen years. Some of these regional spaces have reached a level of development that enables them to play a role on the global scene. This is the case for the European Union which, from the early 1990s, has deepened its institutional architecture and strengthened its international influence. Since the Treaty of Maastricht, the EU has adopted a new type of cooperation agreement in

Correspondence Address: Institut d'Etudes Européennes, Université Libre de Bruxelles, 39, av. F. D. Roosevelt, 1050 Brussels, Belgium, E-mail: sesantan@ulb.ac.be 
order to develop relations with third partners. These agreements have enabled the EU to negotiate region-to-region association with other regional groups. Questions of a political, security, cooperation, environmental and/or trade nature may be tackled within these frameworks. The relations developed with the Common Market of the South (Comision Sectorial para el Mercado Común del Sur - Mercosur) perfectly illustrate the new wave of interregional arrangements that are emerging and shaping global governance. EU-Mercosur relations are based on three pillars: political dialogue, cooperation and trade.

With regard to the EU/Mercosur relations, different issues will be covered in this analysis. Do interregional arrangements enable the EU to increase its external action in 'low politics' and, if so, to what extent? What are the consequences of these interregional agreements for the new regional schemes such as Mercosur? By promoting interregional relations, is the EU becoming an 'external federator' for new regional experiences? In other words, are the new interregional arrangements only a corollary of new regionalism or might interregionalism also be considered a factor of consolidation for regional groups? Because interregional projects or agreements generally include fairly ambitious trade liberalisation agendas, the links between interregionalism and multilateralism are also assessed here. In the light of this case study, could we say that interregionalism arrangements, as well as regionalism, are undermining or encouraging economic multilateralism? By tackling this question, the analysis also focuses on the underlying ideology of new trends in regionalism and interregionalism.

\section{The EU's International Role and New Regionalism in Latin America}

\section{The EU: an Emerging International Actor}

The third summit between the heads of state and government of the European Union, Latin America and the Caribbean, in Guadalajara (Mexico) in May 2004, enabled the $\mathrm{EU}^{1}$ to play a role for the first time on the international scene in its enlarged, 25-country, configuration. This summit was in line with the thinking associated with the 'Rio Process', ${ }^{2}$ which, according to the Rio de Janeiro declaration of June 1999, aimed to achieve a "strategic biregional" (European Parliament 1999: 1) partnership between the EU and Latin America and the Caribbean, supported by a political dialogue as well as cooperation and trade. In so doing, the EU was gradually pursuing its strategy of rapprochement with Latin America and the Caribbean, a sub-continent that, for decades, has been subject to what could only be described as the discretionary domination of the US. At the same time, the EU reiterated its willingness to play a role on the world stage with a single voice, notwithstanding the intra-European divisions that arose just prior to the summit held after the 2003 Iraq war.

The Community's first attempts at rapprochement with some countries or regional groups in Latin America were made in the 1970s. However, it was not until the 1990s that the EU adopted a strategy for all of Latin America 
and the Caribbean (European Commission 1994a). This strategy of bringing together the two sides of the Atlantic was a European initiative, part of the change in the international context. With the end of the Cold War, the European Community - and Japan - began to emerge alongside the US as the new power centres in a world that was increasingly economically interdependent. This emergence of areas that had struggled to find their feet during the 1970s increased the competition among them and the US, helping to weaken the economic position of the US. At that time, the US economy was running out of steam, fuelling debate about its hegemonic decline (Telò 2001).

As globalisation accelerated, the Community's member states became more aware of the difficulties arising from globalisation, such as the ability to play an independent role internationally. The increase in globalisation which, since the 1970s, has resulted in growing economic, financial and trade liberalisation worldwide - has greatly reinforced market ideologies. As a result, the concept of the welfare state has been vigorously questioned. There has also been a gradual dismantling of state barriers to the market economy and international capital movements (Santander 2000a).

The world's states and their economies have become increasingly open to the outside world, making them more interdependent and exposing them to more economic competition. One result, though to different degrees, is less effective national economic policies. This process, to which some states following the example of the US, EU countries and Japan - have deliberately contributed more than others (Gill 1995), has weakened the power of the state. Yet the process has especially benefited the transnational economic actors that play on the same field as states or international bodies. Transnational enterprises have gained most from this change, acquiring more and more power to influence the domestic policies of states and the international relations process (Stopford \& Strange 1991). This trend has also been facilitated by the development of new information technologies, which are structurally linked to deregulation (Telò 1998, 29).

It is against this background of accelerating global competition, states' weakened control over their national economies and the lack of satisfactory global structures that the development of regional structures has become more important in the eyes of states themselves (Gamble \& Payne 1996, 251-252; Ténier 2003). The regional repositioning of states, in the late 1980s, gave rise to the new regionalism. Of course, there are many kinds of regional integration, which is why some prefer to speak of "new regionalisms" (Marchand et al. 1999). The unifying logic behind them varies widely from one regional organisation to another. Differences may depend on whether the organisations are pursuing a strictly trade objective, have common development policies, or bring together the countries of the North and/or the South (Santander 2004b). Some of these groups, taking their cue from Mercosur, were set up later. Others, such as the EU, were reinvigorated. In an unprecedented way, states - just like the US - were converted to the idea of regionalism.

However, the development of European regionalism from the mid-1980s transformed regionalism into an integration phenomenon without precedent, 
defying the pessimistic forecasts made by the realist scholars (Mearsheimer 1990, 199; Waltz 1993). From that moment on, the European bloc began to strengthen its internal structures and to adopt instruments consolidating its visibility and external action. The revival of European integration was part of the growing interdependence movement that resulted from globalisation and the new regionalist wave mentioned above. The end of the Cold War bipolar system offered the EU new international roles and a space to play them. The 1990s allowed the Union - whose activities internationally were no longer conditioned by bipolar rivalry - to embark on the "route of a clearer affirmation of its identity as an international actor" (Remacle 2000, 487). The member states focused on doing more than just the coordination foreseen under European Political Cooperation (EPC). Through the Maastricht Treaty, they gave themselves a Common Foreign and Security Policy (CFSP) allowing "the definition in the long term of a common defence policy, which would result, at the right time, in a common defence" (EU, Selected instruments). Moreover, the instrument of political dialogue ${ }^{3}$ conducted with the external partners was strengthened. This initiative enabled the EU to present itself to others with a single voice and to make good and frequent contacts with third countries and regional groups, to establish links and exchange respective views on international issues.

However, following Europe's inability to move beyond a mainly declarative diplomacy when it came to acting with one voice and acting effectively in 'high politics' arenas - such as ethnic cleansing in the former Yugoslavia, genocide in Rwanda or the war in Iraq - serious doubts were expressed by the realist scholars about the EU's capacity to become a genuine international actor. By institutionalising the CFSP, the European heads of state and government raised expectations that they were not able to meet, due to a lack of compromise. This situation gave rise to the notion of a "capabilityexpectations gap" (Hill 1993). Believing that strategic issues are essentially based on post-bipolar international relations, the realist critics focus as much on the status of the EU as they do on its instruments for carrying out political and strategic actions. Since the EU is not a sovereign entity but more an entity subordinate to member states (it lacks a centralised decisionmaking authority and has no real military capacity of its own), it cannot really be seen as an international actor.

By concentrating on a state-centred and strategic conception, realist scholars reduce the EU's international sphere of activity to the CFSP (Petiteville 2002, 152-53) alone. Yet in other fields ('low politics'), such as foreign trade and cooperation with other countries or regional spaces, the Community has a genuinely influential role worldwide. In world trade, the EU has 20 per cent of the world's total volume of imports and exports, compared with 18 per cent for the US and 10 per cent for Japan. After more than forty years of trade integration, the Union now figures among the planet's leading trading powers. Given that the EU plays a crucial role in drawing up rules for trade multilateralism and globalisation in general, it has a genuine world leadership role to play in the WTO's trade negotiations (Smith \& Woolcock 1999). That is because, with a few exceptions, ${ }^{4}$ the 
European Commission's mandate to negotiate is granted by the Council of Ministers with a qualified majority. The mandate empowers the Commission to draw up a proposal document, to defend member states' trade interests at the WTO and to routinely manage trade policy. European trade policy, therefore, acts as a real lever at the Community level. This policy has allowed the Union to simultaneously develop a network of new agreements - for economic cooperation, association or partnership - such as those negotiated or in the process of conclusion with countries or regional groups of Latin America.

Following the 1992 Treaty of Maastricht, the new cooperation programmes have included a chapter on political dialogue. Besides the 'traditional' chapters on cooperation (technical, economic, trade and/or assistance), these programmes also focus on policy that gives a major role to democratisation, human rights and democratic principles. Many Community cooperation agreements are now distinguished by their 'democratic principles' clause - setting a democratic conditionality — which could be interpreted as an increasing politicisation of economic cooperation (de Wilde d'Estmael 1998). To underline the Union's capacity for international action, we will look at the EU's interregionalist strategy with Mercosur.

\section{The EU and Latin America: From 'Old' to 'New' Interregionalism}

EU/Mercosur relations date from the signing of the Treaty of Asunción (1991), which created Mercosur (Argentina, Brazil, Paraguay and Uruguay). The Union was motivated to develop relations with the South American countries following their political, democratic and economic development. In the late 1980s, Argentina and Brazil moved beyond their long-standing rivalry for regional leadership and engaged in an unprecedented process of political and economic rapprochement, which served as a platform for Mercosur's creation.

The world's leading economic power centres took notice when the region became politically stable and began adopting competitive and outwardlooking economic policies. They saw an opportunity for new outlets for their enterprises. The enthusiasm for this "emerging" (Sautter 1996) area owes much to the markets' unilateral openness policies. Other reasons include racing to privatise public enterprises, deregulation and liberalisation of economic activities, stabilising macro-economic policies to attract Foreign Direct Investment (FDI) and a far-reaching reform of the state. These policies coincided with the creation of Mercosur, which enabled member states to strengthen their neo-liberal reforms and which was a key part of their international economic policy (Cammack 1999, 103). With its 210 million inhabitants, a Gross Domestic Product (GDP) of 1,000 billion US dollars and very strong growth in its intraregional trade, Mercosur quickly became the world's fourth largest trading bloc - after the EU, the North American Free Trade Area (NAFTA) and Japan.

The development of Mercosur illustrates that current regional processes and globalisation are not mutually exclusive trends. By committing themselves 
to a regional initiative, states are obliged to introduce integration policies to increase the credibility of a region's members with external actors - among them potential investors. The conclusion of integration agreements with neighbouring countries obliges a state to exert greater control over its own economic policy, so as to compensate collectively at the regional scale for the loss of national autonomy. But because globalisation was a setback for all isolationist development strategies, the coming together of neo-liberal economic policies has greatly facilitated the postures of regional openness (Hettne 2001, 12; Petiteville 1997, 515). Thus, while globalisation is a series of processes and an ideology of economic management, regionalism must be seen as a manifestation of globalisation; the two developments reinforce one another (Higgott 1997, 280). Hence, it is more useful to talk of neo-regionalism than regionalism, when referring to the new regional organisations and the relaunch of old and now reinvigorated regional agreements (Santander 2000b).

Just like neo-regionalism, 'neo-interregionalism' is not a phenomenon in contradiction with globalisation: neo-interregionalism develops within and is constrained by the global political economy (Grugel 2002, 1). Both these phenomena have become characteristic elements of post-Cold War global governance at multiple levels. Neo-interregionalism is a corollary of the new regional agreements. However, as will be shown later, interregionalism can contribute to the consolidation of regionalism. Thus, there is a two-way relationship between regionalism and interregionalism. ${ }^{5}$

The relations between the EU and Mercosur are based on group-to-group dialogue. This kind of interregionalist initiative, first seen in the 1970s, was related to 'old' regionalism (Hänggi 2000, 4-5). It was the fruit of European Community action. With the Andean Pact, the Community supported the Latin American regional integration efforts. ${ }^{6}$ Support was limited to trade and development cooperation. Inspired by its own integration model, the EU gradually realised that "subjects of a political nature, such as the prevention of conflicts and the war on drugs, could be tackled in a more appropriate way by increasing the efforts made at the regional level" (European Commission 1995a, 2). The creation of European Political Cooperation (EPC) facilitated the development of group-to-group political dialogue (Regelsberger 1998, 2).

A typical example of the 'old' interregionalism is the one the EC developed with the countries of the Central American Common Market (CACM). ${ }^{7}$ The armed conflicts in Central America in the 1980s encouraged the EC to play a major political role as an international broker. The EC established the San José Dialogue with the countries of Central America. This dialogue involved ministerial meetings aimed at achieving peace and democratising the region. The European strategy was based on regular and institutionalised political dialogue, plus a strengthening of development cooperation and support for reinforcement of the regional space (Rubio 2004). However, the old interregionalism was both sporadic and rather limited by the bipolar international context.

With the end of the Cold War, increasing economic interdependence, the emergence of new regionalism and both the deepening of European 
integration and the adoption of new instruments to consolidate its external action (discussed earlier), the EU was able to develop a series of new and much more ambitious interregional agreements. These agreements included the group-to-group association that is being negotiated with Mercosur. The interregional agenda now include mutual trade-liberalisation programmes in keeping with the rules and disciplines of the international economic institutions, such as the WTO. These new programmes are even more ambitious than those at the multilateral level. The compatibility required between the WTO and any other kind of free trade agreement means there is less and less room in the interregional agreements for traditional development cooperation policies, such as the Generalised System of Preferences (GSP) granted unilaterally by the EC to regional areas made up of developing countries such as the Andean Community (CAN) or the CACM. As a result, while neo-interregionalism includes strategic elements, it is distinguished by its neo-liberal economic leanings.

\section{The EU Group-to-Group Strategy Towards Mercosur}

\section{Structure and Actors}

Both the processes of democratisation and economic liberalisation which took place in the late 1980s in South America, as well as the emergence of new regionalism, were important factors for rapprochement with Europe, according to the European Commission (European Commission 1995 b , 5-6). The Commission therefore developed a strategy to institutionalise the growing links between Europe and the countries that constitute Mercosur. 'Third-generation' agreements signed between 1990 and 1992 with each of the four countries of Mercosur replaced the 'empty-shell' agreements of the 1970s and 1980s and revitalised relations. The new agreements are notable for the interest paid to integration and regional cooperation. They are also unique for the inclusion of two clauses. The 'democratic principles' clause calls for respect to the basic principles that stem from a heritage of common values. The 'future developments' clause enables the contracting parties to complete and increase their level of cooperation, moving beyond trade alone (European Commission 1995b, 8).

Behind these new agreements is an EU eager to develop interregional group-to-group relations with Mercosur. The EU capitalised on the interest expressed by Mercosur members to sign an agreement for inter-institutional cooperation. The agreement's main goal was to allow Mercosur to benefit from European experience in regional integration, so Mercosur could eventually become the Community's main partner in relations with the Southern Common Market countries. Following this, the EU began to offer assistance to Mercosur with technical norms, tariffs and agriculture.

The EU provides Mercosur's Secretariat with technical assistance in fields such as training, computer networks, documentation and archives. It also supports Mercosur presidencies in promotion activities such as seminars and conferences. Mercosur also benefits from a programme establishing a 
customs code, which has resulted in Europe-based training courses for customs officials, and missions by European experts to Mercosur customs administrations. Cooperation has also covered assistance from the European Standardisation Committee (CEN) in drawing up technical and quality standards (courses, international meetings, training and annual conferences), as well as help with agricultural projects (institutional aspects, veterinary and phytosanitary sectors). This cooperation has enabled the EU to export its regional governance model and to increase its reputation as an international actor (Santander 2001). Furthermore, the group-to-group strategy has encouraged the harmonisation of economic rules at the regional level so that Mercosur could create its own customs union. A union like this will allow European enterprises to trade freely (without customs barriers) and to enjoy economies of scale. ${ }^{8}$

European technical assistance provided to Mercosur, in addition to the accompanying political and institutional dialogue, proved essential during the period of uncertainty experienced by the South American bloc from 1992 to 1993. At that time, Brazil, led by President Collor, dealt with a serious economic, political and institutional crisis. Argentina, under President Menem, was dissociating itself from its Brazilian neighbour and warmly welcomed the offer from the US to join the group of negotiating countries in NAFTA. The US proposal endangered the objective that Mercosur member states had fixed for themselves under the 1991 Treaty of Asunción, namely the creation by 1995 of a common external tariff with a view to setting up a free trade area and a customs union. Throughout this period of uncertainty, the EU supported Mercosur and developed a substantial political and diplomatic dialogue with the organisation (Hillcoat 1997, 105).

The US proposal was in keeping with its dual-track strategy for trade liberalisation (Payne 1996). While pressing for progress in trade multilateralism, the US envisioned, in the transitional period between the bipolar and post-Cold War eras, a strategic network of regional, transregional and hybrid agreements. ${ }^{9}$ The aim was to integrate all nations into a framework of norms and behaviour - a framework inspired by the United States. To that end, the US became actively involved in Asia-Pacific Economic Cooperation (APEC). In 1990 it launched the Enterprise for the Americas Initiative (EAI), to create a free trade area from Alaska in the north to Tierra del Fuego in the south. The EAI was followed by a hybrid agreement with the four countries of Mercosur under the name ' $4+1$ ', then by NAFTA and the launch of the negotiations for the transregional free trade area of the Americas (FTAA). Contrary to the European vision, the US authorities consider that the Latin American regional spaces are merely temporary and must eventually be absorbed into the broader spaces proposed by the US (Bergsten 1996). The integrationist project under development in South America is viewed with suspicion by the US, as the project is a barrier to its pan-American free trade initiative. The US proposed that pro-American Argentina (then under Menem) should join its project, hoping this would destabilise Mercosur and gradually extend NAFTA to the rest of the Americas. 
The EU was aware of the threat posed by the US project to its strategy of rapprochement with Asia, Latin America and, of course, Mercosur. In a European Commission communication, the EU revealed to what extent the signing of the trade agreements with third countries or groups is economically and strategically important for the Union:

\begin{abstract}
FTAs [free trade areas] are economically beneficial, especially where they help the EU to bolster its presence in the faster growing economies of the world, which is our overriding interest. ... This direct economic justification has also been supplemented by strategic considerations regarding the need to reinforce our presence in particular markets and to attenuate the potential threat of others establishing privileged relations with countries which are economically important to us (European Commission 1995c, 7).
\end{abstract}

The fear of being squeezed out of South America stimulated the EU to react, all the more so because, in capturing 60 per cent of the investments made by European enterprises in Latin America, Mercosur became a leading partner of the EU in the Latin American sub-continent (Giordano \& Santiso 2000, 59). European Commissioner Manuel Marín, who had the Latin America portfolio under the Santer Commission, proposed that the economic and trade links be enhanced in two stages; first, through the setting up of an interregional agreement for economic and trade cooperation and second, through the implementation of an interregional association of a political and economic nature, aimed at encouraging interregional flows, promoting the strategy of investments by enterprises and reinforcing political cooperation at the international level through convergence of the positions of the EU and Mercosur in international bodies (European Commission 1994b).

By approving this strategy, the Essen European Council of December 1994 decided to set up "a new and extended partnership between the two regions" European Council 1994, 16). In the same period, the four presidents of Mercosur member states meeting at the Ouro Preto summit (Brazil) approved this strategic move. On 22 December 1994 in Brussels, a "joint formal declaration of the Council of the European Union and the European Commission, on the one hand, and the member states of Mercosur, on the other hand" stipulated that the parties are committed to "concluding an interregional framework agreement concerning economic and trade cooperation" during 1995 and to "set up a closer political cooperation" (Official Journal of the Communities 1994, 1-2). The European Parliament (European Parliament 1995, 10) and the Economic and Social Committee (European Economic and Social Committee 1996, 135-140) supported the strengthening of relations between the EU and Mercosur. For the European Parliament, a rapprochement such as this preserved the EU's trade role and prevented the whole of the Latin American Southern Cone from falling under the US umbrella. Lastly, the Cannes European Council of June 1995 gave the Commission a mandate to complete the negotiations of an interregional framework agreement with Mercosur; Mercosur heads of state gathered in Asunción in August 1995 to confirm the mandate for negotiations. 
At the Madrid European Council of December 1995, the Union and Mercosur signed the fourth-generation EU-Mercosur Interregional Framework for Cooperation Agreement (EMIFCA), which includes the democratic and future developments clauses of the third-generation agreements. By associating two customs unions, this agreement added something new to international relations. The signing of the framework agreement between two regions was only possible because Mercosur was given a legal status in international law, following a demand made by the EU. This status allowed it to sign international agreements and trade conventions. The hope of gaining access to the European market after the signing of a trade agreement with the Union boosted the development of Mercosur, dispelling the prospect of a weakened bloc in the continental liberalisation movement launched by the US. Thus there was confirmation of the theory that the EU has a role as an "external federator" (Rüland 2002a, 11) for new regional experiences, through its interregionalist projects.

The EMIFCA is based on three pillars. The first institutionalises a regular 'political dialogue' for bi-regional consultation and coordination of the partners' positions on multilateral questions in the international bodies. The second foresees cooperation in fields such as the war on drugs and its consequences, culture, information and communication, as well as training in regional integration with a focus on the social dimension. Mercosur has also requested that there be some cooperation on regional integration, to help the body benefit from European experience. The third and last pillar focuses on strengthening economic and commercial cooperation "which should include a liberalisation of all trade in goods and services, aiming at free trade, in conformity with WTO rules". For the EU, this type of agreement should act as a propellor for multilateral trade liberalisation, since the EU believes that "FTAs promote the principle of open regionalism and can generate trade liberalisation that subsequently spreads to the multilateral field" (European Commission 1995c, 7). In reality, the FTAs must be WTO-plus agreements. In other words, the trade negotiations at the interregional level should aim to achieve more than those at the multilateral level. In this way, by effectively supporting the economic and trade harmonisation of the other regional spaces and then signing interregional trade agreements with them, the EU seeks to drive forward the multilateral liberalisation programmes.

In this process of rapprochement between the EU and Mercosur, transnational companies started progressively and naturally to play a very dynamic role. In a very short time period, the flows of private capital and commercial trade increased exponentially, making Europe the leading investor and trading partner of the Southern Cone, ahead of the US. The Europeans became the principal investors in the South American countries. European enterprises are actively conquering the South American market, benefiting from the regional integration efforts and the privatisation and macro-economic stability policies that result from the Argentine convertibility plan (1991) and the plan Real in Brazil (1994) (both linking the national currency to the US dollar).

The most active investors in the Southern Cone are Spanish, German, French, Dutch and Italian firms. In the race to acquire markets, Spain has 
quickly moved to the head of the European group (ECLAC 2000). Argentina and Brazil now account for more than half of the European capital stock cumulated in Latin America. In Mercosur, 75 per cent of the flows go to Brazil and 24 per cent to Argentina, compared with just one per cent for Paraguay and Uruguay. The European investments are especially concentrated in the service sectors (financial, telecommunications), (Giordano \& Santiso 2000, 59-66). Since the launch of Mercosur, the Southern Cone economies have become a magnet for European transnational companies' strategies. These strategies see the South American market as a new financial horizon, a way of opening up to global competition and staking the EU's place among competitors. For the EU, the relation with Mercosur is strategic. This is why European enterprises wanting to see a free trade agreement signed between the EU and Mercosur created a powerful lobby, MercosurEuropean Business Forum (MEBF) in early 1999, with the support of the European Commission (European Commission's Enterprise Desk 2004b).

A business forum, whose influence springs from regular meetings organised by the negotiators, often accompanies the new trend of interregionalism. To increase their visibility, coordinate their position so as to better promote their interests and to apply pressure on the decision-makers (governments and supranational institutions), these enterprises link up in fora. They can then follow the negotiations and are well positioned to submit their proposals to working groups and policy-makers.

The European Commission neatly sums up this situation:

These [Business Round Tables and Dialogues] are regular events which bring together private economic operators, providing opportunities for developing contacts and stable networks between top industry representatives on both sides, industrial organisations and government officials. The usual outcome of such international meetings is recommendations addressed to the EU and the respective governments on e.g. market access, trade policy and foreign direct investment issues. The European Commission, since the nineties, has sponsored industry-led Industrial Round Tables ... These Round Tables and Business Dialogues produce annual recommendations aiming at the improvement of the business environment. Follow-up and progress reports are used as instruments for efficient implementation of those recommendations on both sides (European Commission's Enterprise Desk 2004a).

There has been considerable growth in the trade of goods. From 1990 to 1998, EU exports to the South American bloc increased by 375 per cent, while the Community's share of exports from Mercosur rose from 14.4 per cent to 21.6 per cent during the same period, resulting in a major trade deficit for the Southern Cone economies (IRELA 1999a, 11-13). The rise in European exports to Mercosur countries was mainly the result of unilateral trade liberalisation policies adopted by the South American governments from the early 1990s. Because of the trade imbalance, however, the Southern Cone national economies became much more dependent on the European market than the EU became on Mercosur. So, in addition to the strong dependence of the South American economies on European capital, a trade 
dependence also developed. While the EU represents 26 per cent of Mercosur's external trade and thus became its leading trading partner, Mercosur only represents 2.9 per cent of EU external trade.

With regard to the structure of trade, the Southern Cone countries although they have reduced the share of their raw materials exports to the European countries since the 1970s - continue to export a large volume of processed foodstuffs to this region. Some 51 per cent of EU imports are agricultural goods, while these products account for only 4.5 per cent of EU exports to Mercosur. 49 per cent of EU purchases are industrial goods, while 95.5 per cent of EU sales are industrial goods (Cienfuegos Mateo 2003, 262). Unlike the South American exports to the EU, the European exports are notable for their high added value. The trade structure between Mercosur and the EU bears a strong resemblance to North-South relations.

\section{Internal Obstacles}

The external trade structure of Mercosur and of the EU is, to some extent, complementary and favours trade rapprochement between the two parties. Nevertheless, South American agricultural exports to the European market face serious obstacles. First, there are numerous European non-tariff barriers. Among them are phytosanitary and antidumping measures that affect the products of key economic sectors in which the Mercosur countries have a comparative advantage. Mercosur countries find themselves competing unfairly for these products with European firms (IRELA 1999b, 6) because of trade barriers that serve to protect so-called 'sensitive' sectors, such as beef, cereals and sugar - sectors that are the subject of specific policies under the EU's Common Agricultural Policy (CAP), which aims to protect European agricultural production. Mercosur countries believe they are put at a particular disadvantage by the CAP which has led to a widening of the Mercosur trade deficit with the EU since 1995. This dossier has proved to be a major obstacle to the launch of negotiations for a trade association between the EU and Mercosur, an association foreseen at the first summit of the EU, Latin America and the Caribbean in June 1999.

To start talks with the South American bloc, the European Commission needed a negotiation mandate from the Council. But major differences arose among the Council's member states regarding the delivery of the negotiation mandate to the Commission, for it was established that a free trade area with Mercosur could seriously harm European agriculture. The majority of the ministers of industry, economics and foreign affairs from the EU member states appeared to support the negotiations with Mercosur. But the French, Irish and Dutch ministers of agriculture and fisheries, under pressure from their domestic lobbies, were opposed to this mandate (IRELA 1999a, 9).

The UK government was of the opinion that the negotiations with Mercosur should not begin before the end of the following WTO round. There was also disagreement in the Santer Commission (1995-1999). The Agriculture Commissioner Franz Fischler, supported by his colleagues from France (Commissioners de Silguy and Cresson) and Ireland (Flynn), also opposed the 
project. Further support for this position came from the European agricultural lobby COPA-COGECA, ${ }^{10}$ which was against any kind of trade agreement with Mercosur (COPA 2004). Those opposed to trade liberalisation justified their position by underlining the 'multifunctional' nature of agriculture in Europe, ${ }^{11}$ a position deemed by Mercosur countries to be a new way of delaying the negotiations. However, the project was supported by Commissioner Marín, the German presidency of the EU (in the first six months of 1999) and the Spanish, Italian and Portuguese governments, not to mention Mercosur-European Business Forum, which was set up specifically (in February 1999) to help the interregional negotiations through a daily dialogue between the entrepreneurs and public authorities of each region (European Commission' Mercosur Desk 2000, 4).

The compromise eventually achieved gave the Commission a mandate to start the negotiations on non-tariff barriers, but delayed any discussions on customs duties until July 2001. These discussions could not, at any rate, be completed before the end of the WTO round, allowing the EU to avoid tackling at the interregional level the question of subsidies for agricultural exports. In any case, as far as the Union is concerned, subjects like these must only be handled in negotiations within the WTO. The Commission, therefore, attended the EU-Mercosur summit (held alongside the Río summit) with a limited negotiating mandate. It took four years from the signing of the EU-Mercosur Interregional Framework for Cooperation Agreement (EMIFCA) for the representatives of the two regional blocs to build a picture of the trade situation and, not without some disappointments for Mercosur, to start negotiations on the non-tariff barriers alone. The negotiations were launched during the first meeting of the Biregional Cooperation Council (BCC), which defined the structure, methodology and schedule for the negotiations and created the Biregional Negotiations Committee (BNC). The committee, to which a Subcommittee on Cooperation (SCC), three Subgroups on specific cooperation areas and three Technical Groups (TG) dealing with trade matters are linked, has become the main body for negotiations between the EU and Mercosur,. The four first meetings of the BNC were limited to questions of methodology, exchange of information and analysis of the basic prerequisites for starting the tariff negotiations. No real progress was made, underlining deadlock in the relations.

\section{External Factors: Facing up to US Transregionalism and Multilateral Negotiations}

Since the US government lacked the Trade Promotion Authority (TPA) ${ }^{12}$ to foster the transregional negotiations in the Americas, the Europeans were not too worried. But in the meantime, the George W. Bush administration which was determined to complete the FTAA negotiations - obtained the TPA from the Congress. Argentina, which was plunged into an economic crisis lasting four years, mainly as a result of the January 1999 Brazilian currency devaluation, started to have misgivings about the raison d'être of Mercosur and wished to become closer to the US in order to foster the FTAA. 
Taking into account these different elements as well as the fragility of Mercosur, the US seized the occasion to propose another trade agreement to Argentina. The US hoped to reactivate conflicts among the members of Mercosur and to destabilise the bloc, because from the US viewpoint the FTAA should be made a reality through country-to-country agreements and thus through NAFTA (Santander 2002a, 494-97). By accepting such a proposal, Argentina risked seeing its international negotiating position weakened to the benefit of the US - as had happened when Mexico joined NAFTA (Carranza 2004, 323).

For the EU, a trade agreement between Argentina and the US would represent the end of the South American bloc, threatening the EU's interregionalist strategy towards Mercosur and reinforcing the FTAA project. The EU fears a possible trade-diversion effect from the FTAA on EU economies. For example, when Mexico became a member of NAFTA, European companies lost about half of the Mexican market. The EU wants to avoid this situation happening again with Mercosur (Santander 2002b, 20-28). European leaders are also aware that if the US project became a reality, it would mean an opening of markets and the creation of new standards and rules that would govern international trade. They fear the emergence of a US-led panAmerican bloc, which could shape the rules of the worldwide economy (European Economic and Social Committee 2004), thus confirming the theory that interregional and transregional arrangements are also distinguished by their strategic aims (Rüland 2002b, 3-4). Such agreements or projects are often in competition, because they allow a state or regional actors to make up for a lack of international influence or to increase their political presence globally. The strategy of the EU towards South America is a response to the US proposal to create a FTAA. The EU is thus trying to avoid being ousted from that continent. It also wants to avoid losing access to and participation in the development of the new international trade rules.

In order not to be excluded from the shaping of these new rules, Europeans tried to re-launch the interregional process by setting up a 48-million euro package to deepen Mercosur (European Commission 2002, 5). The Union also made a more significant trade proposal during the fifth meeting of the BNC in July 2001, making it clear to South American leaders that if Mercosur breaks down, the EU will not sign a trade agreement with individual countries.

The European proposal included all sectors: fishing, services, industry and agriculture. The EU proposed gradual liberalisation over ten years, covering 100 per cent of manufactured goods and 90 per cent of agricultural produce. By doing so, the EU has again contributed to the survival of Mercosur and encouraged its member countries to come up with a counter-proposal on behalf of their regional bloc. European persistence in recognising and supporting regional groups (Andean Community, Central American Integration System,...) as international actors in their own right has, therefore, contributed to the strengthening of their internal structures and the reinforcement of their negotiation power internationally. That does not mean, of course, that the differences thrown up by the trade negotiations 
have been erased. In its proposal, the EU did not offer cuts in subsidies; but it did foresee greater liberalisation for products in which Mercosur is interested through the increase in preferential tariff quotas. However, Mercosur member states were disappointed and this was reflected in their proposal. They even proposed a gradual liberalisation over ten years, covering 86 per cent of manufactured goods and 100 per cent of agricultural produce. The car industry, which is a sensitive issue for Mercosur and a priority for the EU, has not been included in the proposal. Moreover, Mercosur countries, and especially Brazil, are very reticent about opening advantages to external competitors in the areas of services, investments and public procurement.

While the proposals of the EU and Mercosur reflect differences of opinion, they formed an important platform for the negotiators from the two regions and allowed them to make progress in the talks. European trade Commissioner Pascal Lamy was determined to conclude an agreement before the end of the Prodi Commission's mandate in 2004 and he was given a date for the finalisation of the negotiations by the EU Council. During the Guadalajara summit between the heads of state and the governments of the EU, Latin America and the Caribbean, the Europeans officially announced an agreement would be concluded in October 2004; according to officials, the chapters on the political dialogue and cooperation were already completed.

This acceleration in the negotiations owes much to the failure of the September 2003 Cancun WTO Ministerial Conference, as well as the race to reach bilateral trade agreements, which were launched by the US to advance the FTAA. After the failure of the WTO Ministerial Conference of Seattle in 1999, the rich countries, and particularly the EU, placed all their hopes in the Cancun meeting. However, the 13 August 2003 compromise reached between Pascal Lamy and his US counterpart, Robert Zoellick, was not to the liking of some 'emerging economic powers' (Brazil, India, South Africa and China) which created the Group of Twenty (G-20). This European-US compromise, which fixed a common position on the opening of the agricultural market, subsidies and antidumping measures, defined in advance the limited scope of any agricultural agreement. In addition, the EU and the US omitted to give detailed figures and a calendar for the reduction of subsidies for the production and exporting of agricultural produce. A second source of contention, which emerged alongside agriculture, were the 'Singapore issues' (investment, competition, transparency of public-procurement markets and trade facilitation) and the liberalisation of services. These issues are of great importance for the transnational companies of rich countries, but problematic for the developing countries. Given that everyone stuck to their line, the split between the rich countries and the G-20 was quickly confirmed, resulting in the failure of the negotiations (Narlikar \& Wilkinson 2004).

Faced with this fiasco, the US and the EU embarked on a frantic race to create bilateral agreements. The US has, therefore, demonstrated its will to act by trying to regain control of the negotiation process of the project to integrate the Americas. Eager to make progress with the FTAA, Robert Zoellick signed a Free Trade Agreement with Central America (CAFTA) and has initiated the promotion of bilateral trade agreements with countries such 
as Columbia, Ecuador, Peru and Bolivia in the belief that they could 'stimulate the FTAA'. Such agreements, which are tailored to suit particular circumstances, are seen by Washington as a means of bolstering its negotiating position and putting the South American bloc, which is in the process of unification, in a difficult situation. ${ }^{13}$

However, the similarities between the participants and between the topics on the WTO agenda and the FTAA agenda make it harder to set up pan-American transregionalism. The FTAA has given rise to reservations within Mercosur, and above all in Brazil, while the US is refusing to do away with protectionism and agricultural subsidies. It is this very same motivation to see agriculture liberalised at a multilateral level that led Brazil and Argentina to ally with approximately twenty countries with different levels of development and differing interests in a whole range of matters on the global trade agenda. In reality, the fate of the FTAA has always depended on WTO agreements, because US negotiators have set themselves the objective of setting up a WTO-plus agreement, according to which concessions made by the countries must exceed those negotiated within the multilateral framework. The failure at Cancun will, therefore, directly affect the FTAA, since, contrary to Washington's wishes, the aspirations for the project will have to be seriously revised and reduced. In a ministerial dispute in Miami on 21 November 2003 between Brazil and the US, which were co-chairing the final phase of negotiations, Brasilia succeeded in convincing others, notably the US authorities, of the need for a small-scale and $\grave{a}$-la-carte FTAA (dubbed "FTAA-Lite") (Moreira Garcia, 2004, 42). This went against the 'single undertaking' principle made during the ministerial meeting in San José (Costa Rica) in March 1998 and opened up the possibility of creating an international treaty, which included all the topics discussed by the working groups and accepted by all of the parties involved.

In Miami, the FTAA project and Cancun became intertwined. By deciding to negotiate the agricultural dossier solely within the WTO, the Bush administration, therefore, also found itself forced to accept the Brazilian demand to refer negotiations on investment protection, the liberalisation of services, intellectual property and government procurement to the WTO. The Miami compromise allows the thirty-four participating countries to choose the sectors and products in which they would like to participate. Consequently, the project that was still being proposed by the US in the FTAA - and by extension to the south of NAFTA - has been abandoned. To some extent, this is the result of the US turning away from Latin America since the 11 September 2001 attacks, which have focused the country's attention on the fight against terrorism and the wars it has led in Afghanistan and Iraq. Furthermore, the US presidential elections of 2004 prevented the current Bush administration from making any trade concessions, a position that only weakens the US negotiating position under the FTAA project.

As far as the members of the South American bloc are concerned, the Miami agreement is an arrangement that allows Mercosur to focus more 
calmly on its deepening and enlargement towards the rest of the subcontinent. ${ }^{14}$ Moreover, for the Brazilian authorities above all, according to Itamaraty (the Ministry of Foreign Affairs), the Miami Compromise means that the competition mainly from the US and Canada (resulting from a flexible FTAA-Lite) is no longer a threat to the industrial development of Brazil. Mercosur is perceived in Brazil as a means of transforming the country into an industrial power in the region (Turcotte, 2003). It is for this reason that the Brazilian authorities are seeking to establish themselves as the privileged provider of that country's partners for a large number of strategic sectors with high added value, such as capital goods, chemical products, information technology products, motor vehicles and so on.

On behalf of the EU, the European Commission also decided, after the failure of Cancun and within the limits of its mandate, to move forward swiftly on the interregionalist road. Although the FTAA, the trade negotiations between the EU and Mercosur and the WTO constitute three inter-linked processes which are dependent on each other, Mercosur-EU negotiating agenda does not seem to have been affected by the results of the Cancun meeting, unlike the economic integration project of the Americas. The ambitions of the FTAA project have had to be seriously reviewed and reduced. The deadlock in the multilateral talks led the European Commission to forge ahead down the interregional path. The Commission denies that the negotiations with Mercosur are suffering the same fate as those of the FTAA, and continues to advocate a WTO-plus agreement with the South American bloc. It is doing this because such an agreement would allow the EU to forestall the G-20 front, in which Brazil is a leader, and therefore to move ahead more easily in terms of multilateral liberalisation.

To complete the negotiations for an interregional association with Mercosur, in November 2003 the European executive drew up an ambitious working plan known as the 'Brussels Programme', within the limits of its mandate received in June 1999 by the Council of the European Union. This working plan set out five negotiating sessions and two ministerial meetings before October 2004, so as to conclude the Association Agreement with Mercosur before the end of the mandate of the Prodi Commission. The EU trade representative managed to keep the Singapore Issues (investment, competition, transparency of public procurement markets and trade facilitation) which caused so many problems during the meeting in Cancun, on the Mercosur-EU negotiating agenda.

To ensure that the failure of the Cancun negotiations does not jeopardise negotiations between the EU and Mercosur, the European Commission has endeavoured to improve market-access conditions for agricultural products from South America. The innovative aspect of the Commission's proposal lies not in the quota system as such, which was set out in July 2001 at the fifth meeting of the BNC, but rather in the fact that the proposal increases exports from Mercosur countries. In fact, since the Commission has no authority to liberalise these 'sensitive' products, it is drawing up what is known as the 'single pocket principle' to be applied to this quota system. This principle would allow for immediate liberalisation of 50 per cent of export 
quotas and would make the remaining 50 per cent dependent on the outcome of the Doha round of trade talks. The Commission claims not to be operating two pockets - one for multilateral and one for interregional negotiations and is trying to ensure that the system avoids making concessions to Mercosur countries twice over. ${ }^{15}$

Moreover, during the third summit between heads of state and government of the EU, Latin America and the Caribbean, held in late May 2004 in Guadalajara, the EU announced officially that an interregional agreement with Mercosur would be signed by 31 October 2004. However that agreement has not been made at the time of writing, due to various difficulties in the trade field. But despite these hindrances to negotiations, the EU is still working towards reaching a WTO-plus agreement during 2005 with Mercosur.

\section{Conclusion}

Since the early 1990s, various new interregional arrangements have been concluded or are being negotiated. These arrangements can be seen as a corollary of new regionalism, helping to shape the global political economy. New interregionalism as well as new regionalism encourage and legitimise the policies of liberalisation, deregulation and privatisation as part of the development of a globally integrated market. Yet interregionalism also perpetuates trade arrangements with a strong North-South bias. It is often a means to obtain trade concessions when negotiations become blocked at the multilateral level. Hence, this type of relational arrangement is skewed towards economic affairs aimed at opening up markets. The trade negotiations are in conformity with the WTO's rules and disciplines.

Moreover, questions of a political, security, cooperation and/or environmental nature may be addressed in these frameworks. Interregional relations are therefore notable for their strategic nature. The group-to-group strategy of the EU towards Mercosur represents a response to the transregional strategy of the US towards the Americas. Unlike the EU, the US has tried to destabilise Latin American regionalism. The EU constitutes an external federator for regional groups such as Mercosur, which, when facing its European contacts, is under pressure to speak with a single voice. This first involves a considerable effort to harmonise the positions of the South American countries. In addition, the European negotiators are bringing to the negotiating table a number of subjects that are not yet part of common policies within Mercosur. The Southern Cone region's authorities are therefore obliged to develop, with European support, new objectives for their intra-regional agenda. The prospect of concluding an ambitious agreement with the EU increases both the deepening and the international credibility of Mercosur. Although 'new interregionalism' is a result of new regionalism, interregionalism can save and contribute to the consolidation of regional schemes.

Interregionalism is, thus, closely linked to the European Union's intention to play a greater role internationally. The emergence of interregionalist 
relational arrangements should be seen in the light of this intention. The Union's enthusiasm for negotiating interregional agreements is a "form of economic diplomacy in keeping with the 'gaps' of the CFSP and compensates for the discontinuities of this policy through a broad network of institutionalised cooperation in which not only finance and trade circulate but also 'political principles' and 'values'" (Petiteville 2004, 71). So, in spite of the realists' scepticism about the Union's capacity to play an effective international role, the EU has succeeded in turning itself into an international actor. The EU has developed external relations that enable it to promote its interests, policies and internal values, while having recourse to cooperative means rather than military might.

\section{Acknowledgements}

The author would like to express his gratitude to Fredrik Söderbaum for his very helpful comments. He is also grateful for helpful comments received from Eric Remacle, Mario Telò and Luk van Langenhove. However, the author remains solely responsible for any possible errors or incongruities.

\section{Notes}

1. 'European Community' is used here prior to the date of the Maastricht Treaty (1992) which transformed the European Community into the European Union.

2. For a detailed analysis of the Rio Process, see Santander (2004a).

3. The political dialogue alludes to the actions and common positions, declarations or diplomatic management. In reality, this dialogue allows the EU to establish diplomatic contacts with third parties. See Gonzalez (1997).

4. For example, services in the areas of education, health (including social services) and culture, as well as questions to do with investment, where the Council makes unanimous decisions.

5. Thanks to Fredrik Söderbaum for elucidating this point to the author.

6. The Andean Pact (currently the Andean Community) was created in 1969. The members are Bolivia, Colombia, Ecuador, Peru and Venezuela. Chile was a founder member but withdrew in 1973, the year Venezuela joined.

7. The Central American Common Market was created in 1960. The members are Costa Rica, El Salvador, Guatemala, Honduras and Nicaragua.

8. Interview European Commission, DG Enterprise (26 April 2004).

9. According to the theory, membership of transregional arrangements "is more diffuse than in traditional group-to-group dialogues; it does not necessarily coincide with regional groupings and may include member states from more than two regions", while hybrid agreements constitute a relationship between regional groupings and single powers. Hänggi, (2000), pp. 6-7.

10. COPA: Committee of Agricultural Organisations in the European Union; COGECA: General Confederation of Agricultural Cooperatives in the European Union.

11. This idea encompasses the view that agricultural production also takes account of food security, landscape conservation, the protection of animals and employment, etc. Laurent (2001).

12. Authority given to the executive power by the legislative power to negotiate trade deals and submit them for approval without possibility for amendments.

13. One should not forget that Brazil, supported by the others members of Mercosur, played a crucial role in the creation of the G-20, which managed to block negotiations in Cancun, to the great displeasure of the US and the EU.

14. A new step has been accomplished in favour of the South America integration. Indeed, Mercosur, CAN, Chile, Guyana and Surinam signed an agreement, in December 2004 in Cusco (Peru), establishing the South American Community of Nations. Bilbao (2004).

15. Interview with the European Commission, DG Agriculture, 27 April 2004. 


\section{Sebastian Santander}

\section{References}

Bergsten, F. C. (1996) Globalizing Free Trade: The Ascent of Regionalism, Foreign Affairs 3, May/June, pp. 105-120.

Bilbao, L. (2004) Comunidad Sudamericana de Naciones, el Dipló, December, Available at: http:// www.eldiplo.org/semanales.php3, accessed January 2005).

Cammack, P. (1999) Mercosur: From Domestic Concerns to Regional Influence, in: G. Hook \& I. Kearns (eds), Subregionalism and World Order, pp. 95-115 (Great Britain: Macmillan Press Ltd).

Carranza, M. E. (2004) Mercosur and the End Game of the FTAA Negotiations: Challenges and Prospects after the Argentine Crisis, Third World Quarterly, 25(2), pp. 319-337.

Cienfuegos M. M. (2003) Implications of European Union Enlargement for Euro-Mercosur Relations, in: E. Barbé \& E. Johansson-Nogués (eds) Beyond Enlargement: The New Members and New Frontiers of the Enlarged European Union, pp. 257-289 (Barcelona: IUEE).

COPA (2004) EU-Mercosur negotiations represent a big risk for European agriculture, CdP(04)13-1, 27 April.

de Wilde d'Estmael, T. (1998) La dimension politique des relations économiques extérieures de la Communauté européenne (Bruxelles: Bruylant).

ECLAC (2000) Spain Foreign Investment and Corporate Strategies in Latin America and the Caribbean, in: ECLAC (ed.) Foreign Investment in Latin America and the Caribbean 1999, (Chile: ECLAC).

European Commission (1994a) Documento básico sobre las relaciones de la Unión Europea con América Latina y Caribe, Organisation des Etats Ibero-américains. 31 October. Electronic version: www.campus-oei.org/oeivirt/rie07a08.htm, accessed August 2004).

European Commission (1994b) Hacia un fortalecimiento de la política de la Unión Europea respecto al Mercosur. COM (94) 428 final, 19 October.

European Commission (1995a) Appui de la Communauté européenne aux efforts d'intégration économique régionale des pays en développement. COM (95) 219 final.

European Commission (1995b) Unión Europea y América Latina: Actualidad y perspectivas del fortalecimiento de la asociación, 1996-2000. COM(95) 495 final.

European Commission (1995c) Free Trade Areas: An appraisal. SEC(95) 322 final.

European Commission (2002) Mercosur-European Union Regional Strategy Paper 2002-2006. CSP Mercosur 10.09.2002.

European Commission's Enterprise Desk (2004a) Mercosur-EU Business Forum (MEBF). 3 June. Available at: http://europa.eu.int/comm/enterprise/enterprise_policy/business_dialogues/mebf/mebfoverview.htm, accessed August 2004).

European Commission's Enterprise Desk (2004b) Business roundtables and dialogues. Overview. 3 June. Available at: http://europa.eu.int/comm/enterprise/enterprise_policy/business_dialogues/index.htm, accessed August 2004).

European Commission Mercosur Desk (2000) Basic information on Mercosur. June.

European Council (1994) Conclusions de la présidence, Essen. SI (94) 1000, 10 December.

European Economic and Social Committee (1996) Avis du 25 octobre 1995 sur la communication de la Commission au Conseil et Parlement européen pour un renforcement de la politique de l'UE à l'égard du Mercosur. Official Journal C, 22 January.

European Economic and Social Committee (2004) Repercussions of the Free Trade Area of the Americas Agreement on EU relations with Latin America and the Caribbean, Opinion of the EESC. REX/135 — EESC 314/2004 id.

European Parliament (1995) Rapport sur la communication de la Commission au Conseil et au Parlement européen pour un renforcement de la politique de l'Union européenne à l'égard du Mercosur, Working Document. 12 April.

European Parliament (1999) Declaración de Río de Janeiro, América Latina/Caribe/Unión Europea: Primera Cumbre. Press Release, 29 June, Brussels. Available at: www.europarl.eu.int/delegations/ noneurope/idel/d12/docs/cumbrederio/declaracionfinales.htm, accessed [date]).

European Union, Selected instruments taken from Treaties. Electronic version: http://europa.eu.int/abc/ obj/treaties/fr/frtr2b.htm, accessed August 2004).

Gamble, A. \& Payne A. (1996) Regionalism and World Order (London: Macmillan Press Ltd).

Gill, S. (1995) American Hegemony and the Trilateral Commission (New York: Cambridge University Press). 
Giordano, P. \& Santiso, J. (2000) La course aux Amériques: les stratégies des investisseurs Européens dans le Mercosur, Problèmes d'Amérique latine 39, October/December, pp. 55-87.

Gonzalez Sanchez, E. (1997) El dialogo político de la Unión Europea con países terceros, Revista de derecho comunitario europeo 1, January/June, pp. 69-94.

Grugel, J. (2002) Spain, the European Union and Latin America: Governance and Identity in the Making of 'New' Interregionalism, paper presented at the conference 'The Spanish Presidency of the European Union', University of Liverpool, 12 October.

Hänggi, H. (2000) Interregionalism: Empirical and Theoretical Perspectives, paper presented at the workshop 'Dollars, Democracy and Trade: External Influence on Economic Integration in the Americas', Los Angeles, 18 May.

Hettne, B. (2001) Europeanization of Europe: the longer view, paper presented at the "4th PanEuropean Conference of International Relations', Canterbury, 8-10 September.

Higgott, R. (1997) Mondialisation et gouvernement : l'émergence du niveau régional, Politique étrangère 2, pp. 277-292.

Hill, C. (1993) The capability-expectations gap, or conceptualizing Europe's international role, Journal of Common Market Studies 31(3), pp. 305-328.

Hillcoat, G. (1997) Les relations extérieures du Mercosur: bilan et perspectives, Problèmes d'Amérique latine 26 July/September, pp. 101-125.

IRELA (1999a) Las perspectivas de un acuerdo de libre comercio UE-Mercosur y las opciones para la política de EE UU (Madrid: IRELA).

IRELA (1999b) Relaciones Económicas entre el Mercosur y la UE: perpectivas para la nueva década (Madrid: IRELA).

Laurent, C. (2001) La multifoncionnalité de l'agriculture, in: P. Giordano, A. Valladaõ and M.-F. Durand (ed.) Vers un accord entre l'Europe et le Mercosur, pp. 407-423 (Paris: Presses de Sciences Po).

Marchand, M. H., Boas, M. \& Shaw T. (1999) The Political Economy of New Regionalisms, Third World Quarterly 20(5), pp. 897-910.

Mearsheimer, J. J. (1990) Back to the Future: Instability in Europe after the Cold War, International Security 15(2), pp. 194-199.

Moreira Garcia, C. (2004) Negociaciones comerciales OMC-ALCA : Será 2004 una buena cosecha ?, Política Exterior 97, pp. 39-43.

Narlikar, A. \& Wilkinson, R. (2004) Collapse at the WTO: a Cancun post-mortem, Third World Quarterly 25(3), pp. 447-460.

Official Journal of the Communities (1994) Déclaration commune solennelle entre le Conseil de l'UE et la Commission européenne, d'une part, et les Etats membres du Mercosur, d'autre part, C 37731 December.

Payne, A. (1996) The United States and its Enterprise for the Americas, in: A. Gamble \& A. Payne (ed.) Regionalism and World Order, pp. 93-129 (London: Macmillan).

Petiteville, F. (1997) Les processus d'intégration régionale, vecteurs de structurations du système international ? Etudes Internationales XXVIII, pp. 511-533.

Petiteville, F. (2002) L'Union européenne, acteur international «global»? Un agenda de recherche, La revue internationale et stratégique $47, \mathrm{pp} .145-157$.

Petiteville, F. (2004) L'Union dans les relations internationales: du soft power à la puissance?, Questions internationales 7, May/June, pp. 63-72.

Regelsberger, E. (1998) Group-to-Group Dialogues - a Prominent Role in the EU's External Relations, CFSP Forum, pp. 2-3.

Remacle, E. (2000) De l'Euro à la PESC, d'Amsterdam à Helsinki: les balbutiements d'un «acteur» international, Annuaire français de relations internationales I, pp. 487-501.

Rubio, L. A. (2004) L'intégration centre-américaine : entre le modèle européen et le modèle nordaméricain, in: S. Santander (ed.) Globalisation, gouvernance et logiques régionales dans les Amériques, pp. 119-142 (Brussels/Paris: L'Harmattan/GELA-IS).

Rüland, J. (2002a) Inter- and Transregionalism: Remarks on the State of the Art of a New Research Agenda, National Europe Centre Paper n 35 , University of Freiburg.

Rüland, Jürgen (2002b) Interregionalism in International Relations, Working Paper 11, April, University of Freiburg. 


\section{Sebastian Santander}

Santander, S. (2000a) Aux origines de la globalisation, in F. Nahavandi Globalisation et néolibéralisme dans le tiers-monde, pp. 29-42 (Paris: L'Harmattan).

Santander, S. (2000b), Globalisation et néorégionalisme: déclin ou redéfinition du rôle de l'Etat sur la scène internationale?, Studia Diplomatica LIII(5), pp. 93-108.

Santander, S. (2001) La légitimation de l'Union européenne par l'exportation de son modèle d'intégration et de gouvernance régionale. Le cas du Marché Commun du Sud, Etudes internationales XXXIII(1), pp. 51-67.

Santander, S. (2002a) EU-Mercosur interregionalism: Facing up to the South American crisis and the emerging Free Trade Area of the Americas, European Foreign Affairs Review 7(4), pp. 491-505.

Santander, S. (2002b) Reactivación de las negociaciones Euro-MERCOSUR bajo el temor del "síndrome mejicano"?, Revista de Derecho International y del Mercosur, 6(1), pp. 20-28.

Santander, S. (2004a) La stratégie latino-américaine de l'Union européenne: vers un étiolement du processus de Rio?, in: P. Magnette (ed.) La grande Europe, pp. 369-388 (Brussels: Editions de l'Université de Bruxelles).

Santander, S. (2004b) Globalisation, logiques régionales et gouvernance dans les Amériques, in : S. Santander (ed.) Globalisation, gouvernance et logiques régionales dans les Amériques, pp. 5-42 (Brussels/Paris: L'Harmattan/GELA-IS).

Sautter, C. (1996) La découverte des pays émergents, Commentaire 76, pp. 871-878.

Smith, M. \& Woolcock, S. (1999) European Commercial Policy: a Leadership Role in the New Millennium, European Foreign Affairs Review, 4(4), pp. 439-62.

Stopford, J. M. \& Strange, S. (1991) Rival States, Rival Firms: Competition for World Market Shares (Cambridge: Cambridge University Press).

Telò, M. (1998) L’Union européenne dans le monde de l'après-guerre froide, in: M. Telò \& P. Magnette (eds) De Maastricht à Amsterdam, pp. 23-65 (Brussels: Complexe).

Telò, M. (2001) European Union and New Regionalism: Regional Actors and Global Governance in a Post-hegemonic Era (England: Ashgate).

Ténier, J. (2003) Intégrations régionales et mondialisation (Paris: La documentation française).

Turcotte, S. F. (2003) Le multilatéralisme brésilien et le libre-échange dans les Amériques, in: C. Deblock and S. F. Turcotte, Suivre les Etats-Unis ou prendre une autre voie? pp. 81-110 (Brussels: Bruylant).

Waltz, K. (1993) The New World Order, Millennium 22, pp. 187-195. 